\title{
Determinan Kemauan Pelaku Usaha Mikro, Kecil, Dan Menengah Menjadi Wajib Pajak
}

\author{
Achmad Iqbal $^{1}$, Sari Narulita ${ }^{2}$, M. Iswahyudi ${ }^{3}$ \\ Fakultas Ekonomi, Universitas 17 Agustus 1945 Banyuwangi, Indonesia \\ E-mail : iqbalachmad@untag-banyuwangi.ac.id
}

Direvisi : 04 /01/2020 Dipublikasikan : 27/01/ 2020

\begin{abstract}
Abstrak
Untuk melaksanakan kewajiban pajaknya, seseorang atau badan harus terlebih dahulu menjadi wajib pajak. Diharapkan dengan meningkatkan jumlah wajib pajak, pendapatan negara dari sektor pajak juga akan meningkat. Penelitian ini bertujuan untuk menguji secara empiris faktor-faktor penentu kesediaan pelaku UMKM untuk menjadi wajib pajak. Penelitian ini menggunakan pendekatan kuantitatif. Metode pengumpulan data menggunakan teknik survei. Sebanyak 127 UMKM di Banyuwangi adalah sampel penelitian. Analisis data menggunakan WarpPLS. Hasil penelitian menunjukkan bahwa sikap dan kontrol perilaku mempengaruhi minat UMKM untuk menjadi wajib pajak. Penelitian ini juga membuktikan bahwa kontrol perilaku dan minat mempengaruhi perilaku UMKM untuk menjadi wajib pajak. Namun, penelitian ini membuktikan bahwa norma subjektif dan pertanggungjawaban pemerintah tidak mempengaruhi minat.
\end{abstract}

Kata kunci : Kontrol Perilaku, Minat, Norma Subjektif, Perilaku, Sikap.

\begin{abstract}
In order to carry out its tax obligations, a person or entity must first become a taxpayer. It is hoped that by increasing the number of taxpayers, the state income from the tax sector will also increase. This study aims to empirically examine the determinants of the willingness of SMEs to become taxpayers. This study uses a quantitative approach. The data collection method uses survey techniques. A total of 127 SMEs in Banyuwangi are the study sample. Data analysis using SEM-PLS. The results showed that attitudes and behavioral control affect the interests of SMEs to become taxpayers. This study also proves that behavioral control and interest affect the behavior of SMEs to become taxpayers. However, this study proves that the norms of subjectivity and government accountability do not affect interest.
\end{abstract}

Keyword : Behavioral control, Norms Of Subjectivity, Behavior, Interest, Attitude 
Determinan Kemauan Pelaku UMKM... Achmad Iqbal

\section{Pendahuluan}

Doi (https://doi.org/10.33506/sl.v9i1.692)

Banyuwangi merupakan salah satu kabupaten di Jawa Timur yang mengalami lonjakan positif dari segi pembangunan daerah. Banyuwangi saat ini memiliki beragam potensi untuk dikembangkan, termasuk dari sisi ekonomi. Peningkatan dari sisi ekonomi dan bisnis berdampak pada potensi penerimaan pajak semakin tinggi. Berdasarkan data wajib pajak tahun 2016 dan 2017, jumlah wajib pajak di Banyuwangi meningkat, hal ini dapat dilihat dalam tabel 1.1 sebagai berikut.

Tabel 1 Jumlah Wajib Pajak Kabupaten Banyuwangi Tahun 2016 dan 2017

\begin{tabular}{lrrrr}
\hline \multirow{2}{*}{ Keterangan } & \multicolumn{2}{c}{ Tahun 2016 } & \multicolumn{2}{c}{ Tahun 2017 } \\
\cline { 2 - 5 } & WP Terdaftar & Wajib SPT & WP Terdaftar & Wajib SPT \\
\hline WP Badan & 7.829 & 3.480 & 8.905 & 3.914 \\
\hline WP OP Karyawan & 75.859 & 57.143 & 82.432 & 40.065 \\
\hline WP OP Nonkaryawan & 28.537 & 12.432 & 34.431 & 15.519 \\
Total & & & & $\mathbf{1 2 5 . 7 6 8}$ \\
\hline
\end{tabular}

Sumber: Lakin DJP, 2017

Diantara wajib pajak yang telah disebutkan diatas, salah satu yang menjadi wajib pajak adalah pelaku Usaha Mikro, Kecil, dan Menengah (UMKM). Dari aspek perpajakan, sektor UMKM cukup bisa diandalkan untuk menjadi sumber pendapatan negara. Bertambahnya UMKM baru tentu menjadi peluang bagi meningkatnya pendapatan negara, dengan syarat bahwa meningkatnya UMKM harus berbanding lurus dengan kepatuhan pelaku UMKM dalam melaksanakan kewajiban perpajakannya. Oleh karena itu, terlebih dulu UMKM harus menjadi wajib pajak sebagai syarat seseorang/badan dapat melaksanakan kewajiban pajaknya.

Kemauan menjadi wajib pajak merupakan hal yang vital bagi keberlanjutan pendapatan pajak negara. Kemauan seseorang/badan untuk menjadi wajib pajak secara teoritis dapat dijelaskan dengan menggunakan teori perilaku terencana (Theory of Planned Behavior) yang dikemukakan oleh (Ajzen, 1991). (Baridwan, 2012) menjelaskan bahwa untuk memprediksi perilaku manusia dapat digunakan TPB sebagai salah satu dasar teorinya. Menurut TPB, perilaku seseorang ditentukan oleh minat, dimana minat tersebut dipengaruhi oleh sikap, norma subjektif, dan kontrol perilaku.

Kaitannya dengan kemauan seseorang menjadi wajib pajak, TPB menjelaskan bahwa seseorang memiliki kemauan menjadi wajib pajak ditentukan oleh minatnya akan hal tersebut. Minat seseorang untuk menjadi wajib pajak di pengaruhi oleh sikap, norma subjektif dan kontrol perilaku. Sikap diartikan sebagai gambaran perasaan seseorang tentang suka atau tidak sukanya secara umum terhadap suatu stimulus. Norma subjektif mengarah pada persepsi individu terkait dengan pengaruh orang-orang disekitarnya untuk harus atau tidak melakukan suatu tindakan. Dengan kata lain, seseorang mau menjadi wajib pajak dipengaruhi oleh bagaimana orang-orang disekitarnya mendorongnya untuk menjadi wajib pajak. Sedangkan kontrol perilaku diartikan 
Determinan Kemauan Pelaku UMKM... Achmad Iqbal

Doi (https://doi.org/10.33506/sl.v9i1.692) sebagai kemudahan atau kesulitan yang dirasakan karena suatu tindakan yang dilakukan. Kemauan seseorang untuk menjadi wajib pajak dipengaruhi oleh pengalamannya di masa lalu atau informasi yang diperolehnya tentang bagaimana menjadi wajib pajak.

Selain berdasarkan teori TPB, determinan kemauan UMKM menjadi wajib pajak juga dapat dijelaskan dengan teori psikologi fiskal (Ferrari \& Randisi, 2013). Teori ini fokus pada analisis mengapa individu menolak terhadap pajak. Menurut (Kogler, Batrancea, Nichita, \& Pantya, 2013), persepsi pelaku UMKM atas pemerintah sebagai fiskus menjadi faktor penting yang menstimulus munculnya niat memenuhi kewajiban menjadi wajib pajak secara sukarela.

Beberapa penelitian sebelumnya (Lunney, Cunningham, \& Eastin, 2016; Fuadi \& Mangoting, 2013 ; Wicaksono, 2016 ; Hendri, 2016) tentang sikap wajib pajak masih didominasi pada analisis tentang kepatuhan wajib pajak dalam hal ini pelaku UMKM. Artinya peneliti fokus pada UMKM yang sudah berstatus menjadi wajib pajak. Padahal, kemauan UMKM untuk menjadi wajib pajak merupakan awal dan penentu dari tingkat penerimaan pajak. Jika kesadaran untuk menjadi wajib pajak saja masih kurang, maka upaya peningkatan pendapatan negara melalui pajak menjadi semakin sulit dicapai.

Penelitian ini merupakan pengembangan dari penelitian yang dilakukan oleh (Widyati, 2018). Penelitian ini mencoba menambahkan beberapa variabel dan mengembangkan model penelitian. Perbedaan mendasar penelitian ini dengan (Widyati, 2018) adalah terletak pada teori yang digunakan. (Widyati, 2018) menggunakan exchange theory sedangkan penelitian ini menggunakan TPB dan teori psikologi fiskal. Perbedaan tersebut mengakibatkan variabelvariabel penelitian yang berbeda walaupun sama-sama melakukan penelitian tentang kemauan pelaku UMKM menjadi wajib pajak. Penelitian ini bertujuan untuk menguji pengaruh sikap, kontrol perilaku, norma subjektif, pertanggungjawaban pemerintah terhadap minat pelaku UMKM menjadi wajib pajak. Selain itu, penelitian ini juga bertujuan untuk menguji pengaruh kontrol peilaku dan minat terhadap perilaku dari pelaku UMKM menjadi wajib pajak.

\section{Metode Penelitian}

Penelitian ini dilakukan sesuai kerangka konseptual penelitian yang dapat dilihat dalam gambar berikut :

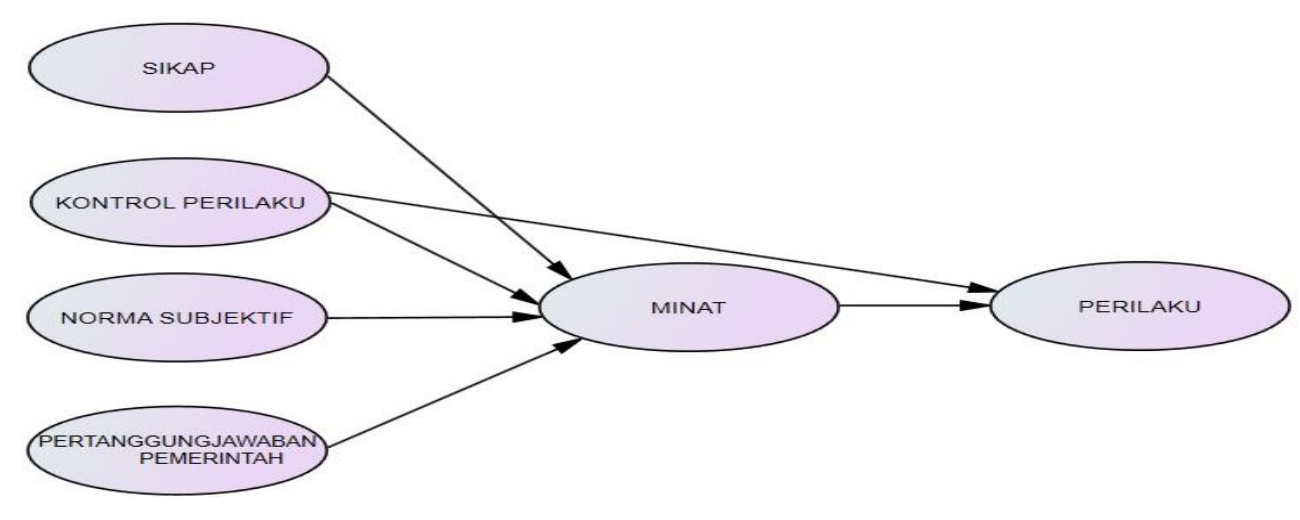

Gambar 1 Rerangka Konseptual 
Determinan Kemauan Pelaku UMKM...

Achmad Iqbal

Doi (https://doi.org/10.33506/sl.v9i1.692)

Berdasarkan kerangka konseptual penelitian, maka hipotesis penelitian dapat dikembangkan sebagai berikut :

\section{Pengaruh Sikap terhadap Minat pelaku UMKM menjadi WP}

Sikap merupakan suatu evaluasi seorang akan perasaanya untuk melakukan sebuah perilaku (Ajzen, 1991). Dalam perpajakan, sikap bisa dipandang menjadi sesuatu yang merugikan ataupun menguntungkan (Feld \& Frey, 2007). Ini berarti apabila individu merasa perilaku patuh terhadap peraturan perpajakan itu merupakan hal yang menguntungkan, maka individu tersebut akan bersikap positif, sikap positif inilah yang akan menciptakan kepatuhan pajak.

(Bobek \& Hatfield, 2003 ; Mustikasari, 2007; Marandu, Mbekomize, \& Ifezue, 2015) menyatakan bahwa sikap yang baik atau positif terhadap peraturan perpajakan akan memiliki pengaruh yang positif pula terhadap minat seseorang untuk memenuhi kewajiban perpajakannya. Berdasarkan uraian diatas, maka dapat dirumuskan hipotesis sebagai berikut :

H1: Sikap berpengaruh positif terhadap Minat pelaku UMKM untuk menjadi WP

\section{Pengaruh Norma Subjektif terhadap Minat pelaku UMKM menjadi WP}

Norma subjektif diartikan sebagai perasaan seseorang terhadap tekanan sosial untuk melakukan atau tidak melakukan suatu perilaku (Ajzen, 1991). Dalam hal perpajakan, norma subjektif mengarah pada pengaruh atau tekanan lingkungan disekitar individu untuk dapat mempengaruhi individu mematuhi atau tidak mematuhi peraturan perpajakan (Lubis, 2011). Jadi jika pada lingkungan tersebut ada pihak-pihak yang dianggap penting oleh orang tersebut mempunyai sikap positif terhadap perilaku kepatuhan pajak, maka WP tersebut akan cenderung patuh terhadap kewajiban perpajakannya.

Meta analisis yang dilakukan (Marandu et al., 2015) terhadap hal-hal yang mempengaruhi perilaku kepatuhan pajak di Dunia, menemukan bahwa norma subjektif menjadi salah satu pemicu minat seseorang untuk patuh atau tidak patuh dalam pelaksanaan kewajiban perpajakannya. Atas hasil penelitian tersebut peneliti mencoba menguji kembali pada pelaku UMKM yang ada di Banyuwangi, sehingga dapat dirumuskan hipotesis sebagai berikut :

H2: Norma Subjektif berpengaruh positif terhadap Minat Pelaku UMKM untuk menjadi WP

\section{Pengaruh Kontrol Perilaku terhadap minat dan Perilaku pelaku UMKM menjadi WP}

Kontrol perilaku didefisinisikan sebagai kemudahan atau kesulitan yang dirasakan oleh individu atas sebuah perilaku (Ajzen, 1991). Kontrol perilaku menjadi penentu apakah individu harus terlibat atau tidak terlibat dalam sebuah perilaku tertentu berdasarkan tingkat kontrol dirinya (Bobek \& Hatfield, 2003). Dalam bidang perpajakan, kontrol perilaku merujuk pada seberapa besar kontrol kepercayaan individu pada perilaku spesifik, misalnya melaporkan 
Determinan Kemauan Pelaku UMKM... Achmad Iqbal

Doi (https://doi.org/10.33506/sl.v9i1.692) penghasilan lebih rendah. Jika individu tersebut yakin ia mampu melaporkan penghasilan lebih rendah, maka ia akan melakukannya.

Hubungan kontrol perilaku terhadap minat dalam bidang perpajakan didukung oleh beberapa hasil riset. (Bobek \& Hatfield, 2003; Mustikasari, 2007; Marthadiansyah, Meutia, \& Mukhtgarudin, 2013) menemukan bahwa kontrol perilaku berpengaruh terhadap minat untuk patuh atau tidak patuh terhadap peraturan perpajakan.

Dalam teori perilaku terencana, kontrol perilaku selain berpengaruh terhadap minat juga mempengaruhi secara langsung terhadap perilaku. (Ajzen, 1991) menyatakan bahwa seseorang akan melakukan suatu perilaku jika ia memiliki keyakinan atas kemampuannya sendiri untuk dapat melakukan sesuatu. Penelitian yang dilakukan (Mustikasari, 2007) mengenai pengaruh kontrol perilaku pada WP badan terhadap perilaku kepatuhan pajak di Surabaya menemukan bahwa kontrol perilaku menjadi penentu utama WP badan dalam memenuhi kewajiban perpajakannya. Berdasarkan uraian diatas, maka dapat dirumuskan hipotesis sebagai berikut :

$\mathrm{H} 3 \mathrm{a}$ : Kontrol Perilaku berpengaruh positif terhadap minat pelaku UMKM untuk menjadi WP

$\mathrm{H} 3 \mathrm{~b}$ : Kontrol Perilaku berpengaruh positif terhadap perilaku pelaku UMKM untuk menjadi WP

\section{Pengaruh Pertanggungjawaban Pemerintah atas Dana Pajak terhadap Minat pelaku UMKM menjadi WP}

Pertanggungjawaban pemerintah atas dana pajak berkaitan dengan anggapan atau perasaan WP tentang sistem perpajakan dan penggunaan dana pajak yang dilakukan oleh pemerintah. Persepsi terhadap pemerintah mengarah pada bagaimana kelompok-kelompok sosial memberi dukungan atau sebaliknya menjadi oposisi terhadap sistem perpajakan yang berlaku (Hidayat \& Nugroho, 2010). WP cenderung untuk melakukan perilaku penghindaran pajak jika mereka merasakan adanya ketidak adilan dalam sistem perpajakan (Richardson, 2008). Pertanggungjawaban itu penting karena sebagian besar WP tidak mengetahui mengenai belanja publik, jumlah pajak yang ditampung, wujud realisasinya, durasinya serta dampaknya untuk jangka pendek maupun jangka menengah (Ferrari \& Randisi, 2013).

Hubungan antara pertanggungjawaban pemerintah terhadap minat dalam bidang perpajakan didukung secara empiris oleh beberapa penelitian sebelumnya. (Lubis, 2011) menemukan bahwa minat untuk memenuhi segala peraturan perpajakan dipengaruhi oleh perasaan WP atas pemanfaatan dan pertanggungjawaban pajak oleh pemerintahnya. Berdasarkan uraian diatas maka dapat dirumuskan hipotesis :

H4: Pertanggungjawaban Pemerintah Atas Dana Pajak berpengaruh positif terhadap minat pelaku UMKM untuk menjadi WP.

\section{Pengaruh minat terhadap Perilaku dari Pelaku UMKM Uuntuk menjadi WP}

Dalam bidang perpajakan perilaku kepatuhan dapat dipelajari dengan cara menganalisis keputusan seseorang mengenai pilihan membayar atau tidak membayar, mendaftar atau tidak 
Determinan Kemauan Pelaku UMKM... Achmad Iqbal

Doi (https://doi.org/10.33506/sl.v9i1.692) mendaftar (Feld \& Frey, 2007). Minat merupakan tingkatan yang menyatakan seberapa jauh keinginan seseorang untuk berusaha keras dalam melakukan sebuah perilaku, atau usaha yang direncakanan individu untuk mengusahakan suatu perilaku tertentu (Ajzen, 1991). Hubungan minat terhadap perilaku dalam konteks perpajakan adalah mengenai minat untuk mematuhi peraturan perpajakan seseorang untuk memunculkan atau melakukan perilaku patuh terhadap peraturan perpajakan.

(Fuadi \& Mangoting, 2013) menyatakan bahwa perilaku kepatuhan seseorang terhadap peraturan perpajakan dipengaruhi oleh minatnya untuk patuh terhadap ketentuan perpajakan. Jadi jika minat seseorang untuk tidak mematuhi peraturan perpajakan itu tinggi, maka akan semakin tinggi pula kecenderungan seseorang untuk melakukan perilaku tidak patuh, begitu juga sebaliknya. Berdasarkan analisis tersebut maka dapat dirumuskan hipotesis :

H5: Minat pelaku UMKM untuk menjadi WP berpengaruh positif terhadap Perilaku.

Penelitian ini merupakan penelitian kuantitatif. Penelitian jenis ini memiliki kelebihan antara lain adalah memiliki kejelasan dalam penentuan sampel dan instrumen data. Sesuai dengan tujuan penelitian, yaitu untuk membuktikan pengaruh sikap minat UMKM menjadi WP, norma subjektif, kontrol perilaku, dan pertanggungjawaban pemerintah atas dana pajak.

Data yang digunakan dalam penelitian ini bersumber dari data primer, pengumpulan data menggunakan metode survey. Data diperoleh dengan mengirimkan kuesioner ke UMKM di Banyuwangi yang belum terdaftar sebagai WP. Sampling dilakukan dengan teknik Quota Sampling terhadap 15 Desa Di Kabupaten Banyuwangi dengan 10 UMKM pada masing-masing desa. Analisis data dalam penelitian ini dilakukan dengan beberapa tahapan antara lain yakni uji validitas dan reliabilitas yang kemudian dilakukan uji inner model dan uji outer model.

\section{Hasil dan Pembahasan}

Pengumpulan data penelitian ini dimulai dari bulan Mei sampai dengan bulan Juni 2019. Sebanyak 150 kuesioner telah disebar, terdapat 23 kuesioner tidak terisi lengkap dan tidak dapat digunakan. Sehingga sampel penelitian ini adalah 127 data. Hipotesis diterima jika hasil uji menunjukkan bahwa nilai $p$ value lebih kecil dari nilai signifikansi.

Uji validitas dalam penelitian ini terdiri dari dua pengujian, yakni uji validitas konvergen dan diskriminan. Berikut hasil pengujian validitas konvergen dalam penelitian ini.

Tabel 2 Uji Validitas Konvergen

\begin{tabular}{ll}
\hline Konstruk & AVE \\
\hline Sikap (SKP) & 0,642 \\
Kontrol Perilaku (KP) & 0,748 \\
Norma Subjektif (NS) & 0,811 \\
Pertanggungjawaban Pemerintah (PP) & 0,734 \\
Minat (MNT) & 0,733 \\
Perilaku (PR) & 0,911 \\
\hline
\end{tabular}

Sumber : Data Diolah 
Determinan Kemauan Pelaku UMKM... Achmad Iqbal

Doi (https://doi.org/10.33506/sl.v9i1.692)

Tabel 2 menunujukkan bahwa hasil uji validitas konvergen dapat dikatakan seluruh konstruk penelitian memnuhi syarat validitas konvergen. Hal ini dikarenakan nilai AVE dari seluruh konstruk penelitian telah melebihi 0,5 .

Selanjutnya, untuk pengujian validitas diskriminan dilakukan dengan melihat akar kuadrat AVE yang terdapat dalam output correlations among latent variable. Hasilnya menunjukkan bahwa akar kuadrat AVE pada setiap konstruk sudah lebih besar dari korelasi antar variabel laten pada kolom yang sama.

Tabel 3 Uji Validitas Diskriminan (Akar Kuadrat AVE)

\begin{tabular}{lc}
\hline Konstruk & Akar Kuadrat AVE \\
\hline Sikap (SKP) & 0,801 \\
Kontrol Perilaku (KP) & 0,865 \\
Norma Subjektif (NS) & 0,900 \\
Pertanggungjawaban Pemerintah (PP) & 0,857 \\
Minat (MNT) & 0,856 \\
Perilaku (PR) & 0,955 \\
\hline
\end{tabular}

Sumber : Data Diolah

Hasilnya menunjukkan bahwa akar kuadrat AVE dari seluruh konstruk sudah lebih besar dari korelasi antar variabel laten pada kolom yang sama. Sehingga dapat disimpulkan seluruh konstruk memenuhi kriteria validitas diskriminan. Validitas konvergen juga dapat diuji dengan melihat skor cross loading masing-masing konstruk. Nilai loading yang kurang dari 0,7 dihapus sebagai indikator. Hasil uji validitas diskriminan pada seluruh indikator dapat disimpulkan telah memenuhi kriteria pengujian karena nilai loading lebih dari 0,7 untuk semua konstruk. Hasilnya dapat dilihat dalam tabel berikut.

\begin{tabular}{lcc}
\multicolumn{3}{c}{ Tabel 4 Hasil Uji Validitas Diskriminan (Nilai Cross Loading) } \\
\hline Konstruk & Indikator & Nilai Loading \\
\hline Sikap (SKP) & SKP1 & 0,708 \\
& SKP2 & 0,900 \\
Kontrol Perilaku (KP) & SKP3 & 0,868 \\
& SKP5 & 0,709 \\
Norma Subjektif (NS) & KP1 & 0,888 \\
& KP2 & 0,858 \\
& KP3 & 0,847 \\
Pertanggungjawaban Pemerintah (PP) & NS1 & 0,931 \\
& NS2 & 0,937 \\
& NS3 & 0,830 \\
& PP2 & 0,864 \\
Minat (MNT) & PP3 & 0,846 \\
& PP4 & 0,901 \\
Perilaku (PR) & PP5 & 0,814 \\
& MNT1 & 0,869 \\
\hline
\end{tabular}

Sumber : Data Diolah 
Determinan Kemauan Pelaku UMKM... Achmad Iqbal

Doi (https://doi.org/10.33506/sl.v9i1.692)

Tahap pengujian selanjutnya adalah uji reliabilitas konstruk. Parameter yang digunakan dalam uji reliabilitas adalah nilai cronbach's alpha dan composite reliability.

Tabel 5 Hasil Uji Reliabilitas (Nilai Cronbach's Alpha dan Composite Reliability)

\begin{tabular}{lcc}
\hline \multicolumn{1}{c}{ Konstruk } & Cronbach's Alpha & Composite Reliability \\
\hline Sikap (SKP) & 0,809 & 0,876 \\
\hline Kontrol Perilaku (KP) & 0,831 & 0,899 \\
\hline Norma Subjektif (NS) & 0,882 & 0,928 \\
\hline Pertanggungjawaban Pemerintah (PP) & 0,879 & 0,917 \\
\hline Minat (MNT) & 0,817 & 0,892 \\
\hline Perilaku (PR) & 0,903 & 0,954 \\
\hline
\end{tabular}

Sumber : Data Diolah

Tabel 5 menunjukan seluruh konstruk memiliki nilai cronbach's alpha dan composite reliability sudah melebihi 0,7 . Artinya seluruh konstruk dalam penelitian ini telah memenuhi kriteria dan dapat dikatakan reliable.

\section{Uji Hipotesis}

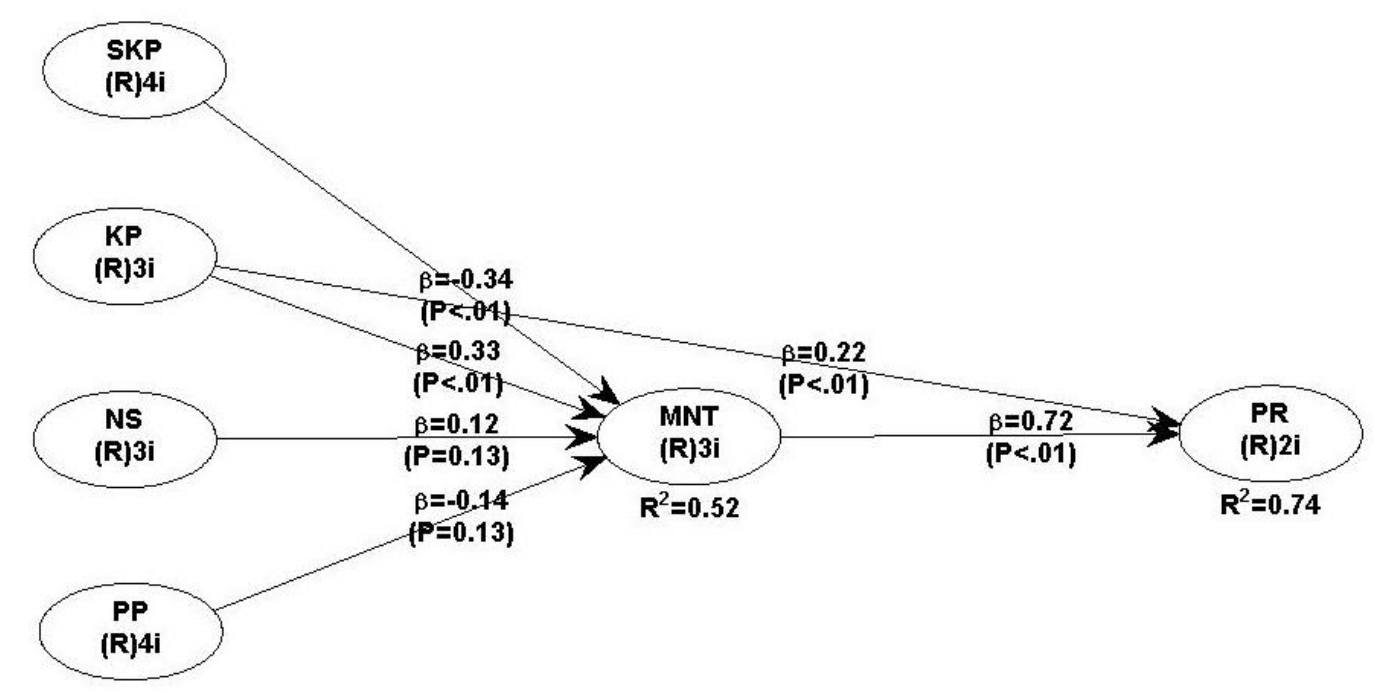

\section{Gambar 2 Hasil Uji Hipotesis}

Berdasarkan Gambar 2, diketahui bahwa $\mathrm{R}^{2}$ kontruk Minat memiliki nilai 0,57 atau 57\%. Artinya kontruk Minat dapat dijelaskan oleh konstruk endogen sebesar 57\% sedangkan sisanya dijelaskan oleh konstruk lain yang tidak dimasukkan dalam penelitian. Nilai $\mathrm{R}^{2}$ kontruk Perilaku memiliki nilai 0,74 atau $74 \%$. Artinya kontruk Perilaku dapat dijelaskan oleh konstruk endogen sebesar $74 \%$ sedangkan sisanya dijelaskan oleh konstruk lain yang tidak dimasukkan dalam penelitian. 
Determinan Kemauan Pelaku UMKM... Achmad Iqbal

Doi (https://doi.org/10.33506/sl.v9i1.692)

Uji hipotesis dilakukan dengan melihat nilai $\mathrm{p}$ value dan path coefficient. Hipotesisi pada Penelitian ini tanpa mempertimbangkan arah hubungan, jika besarnya $\mathrm{p}$ value kurang dari 0,05 maka hipotesis diterima.

\section{Pengaruh Sikap Terhadap Minat Pelaku UMKM menjadi Wajib Pajak}

Hasil analisis menunjukkan bahwa terdapat pengaruh antara sikap dan minat pelaku UMKM untuk menjadi wajib Pajak, sehingga hipotesis pertama penelitian ini diterima. Pengaruh ini menunjukkan nilai berlawanan (negatif). Hal ini mengindikasikan bahwa sikap menjadi penentu minat pelaku UMKM untuk menjadi wajib pajak. Ketika pelaku UMKM memiliki sikap (perasaan) yang negatif terhadap pajak, maka minatnya (keinginannya) untuk menjadi WP muncul, begitupun sebaliknya, ketika pelaku UMKM mempunyai perasaan positif, (baik) terhadap pajak, maka keinginannya untuk menjadi wp sangatlah rendah. Jadi dapat disimpulkan bahwa sikap menjadi sesuatu yang dipandang menguntungkan juga dapat menjadi sesuatu yang merugikan (Basri \& Surya, 2014).

Hasil penelitian ini mendukung penelitian yang dilakukan oleh (Bobek \& Hatfield, 2003; Mustikasari, 2007; Marandu et al., 2015). Hasil penelitian menyatakan bahwa sikap pelaku usaha berpengaruh terhadap peraturan dan ketentuan perpajakan akan memunculkan pengaruh yang positif pula terhadap keinginan seseorang untuk memenuhi kewajiban perpajakannya (Marandu et al., 2015). Kewajiban perpajakan yang dimaksud dalam penelitian, jika dihubungkan dengan keinginan wajib pajak untuk menjadi wajib pajak adalah, ketika pelaku UMKM telah memenuhi syarat subjektif dan syarat objektif mereka harus segera mendaftarkan diri sebagai wajib pajak.

\section{Pengaruh Norma Subjektif terhadap Minat Pelaku UMKM menjadi Wajib Pajak}

Hasil penelitian ini menunjukkan bahwa norma subjektif tidak berpengaruh terhadap minat pelaku UMKM untuk menjadi wajib pajak, sehingga hipotesis kedua dalam penelitian ini ditolak. Hal ini menunjukkan bahwa keinginan pelaku UMKM untuk menjadi wajib pajak tidak dipengaruhi oleh tekanan orang-orang disekitar, misalnya keluarga, teman ataupun lingkungan. Jadi meskipun lingkungan sekitar, orang-orang terdekat, keluarga, teman telah memenuhi kewajiban perpajakannya (menjadi wajib pajak), individu (sebagai pelaku usaha) tidak terpengaruh untuk ikut-ikutan menjadi wajib pajak.

Hasil penelitian ini bertolak belakang dengan penelitian meta analisis yang dilakukan oleh (Marandu et al., 2015) yang menyatakan bahwa norma subjektif menjadi salah satu faktor pemicu seseorang untuk patuh atau tidak patuh terhadap peraturan dan ketentuan perpajakan. Perbedaan hasil penelitian ini dikarenakan adanya perbedaan pada objek yang diteliti. (Marandu et al., 2015) meneliti pada masyarakat pada umumnya, sedangkan pada penelitian ini objek penelitiannya dilakukan pada UMKM. UMKM sebagai 'seorang pengusaha' tentu memiliki sikap percaya diri dan tidak mudah terpengaruh oleh orang lain, sehingga meskipun orang lain, 
Determinan Kemauan Pelaku UMKM... Achmad Iqbal

Doi (https://doi.org/10.33506/sl.v9i1.692) orang-orang sekitar, teman, keluarga dan rekat sejawat telah memenuhi kewajibannya dalam hal perpajakan, mereka tidak terpengaruh terhadap hal tersebut.

\section{Pengaruh Kontrol Perilaku terhadap Minat Pelaku UMKM menjadi Wajib Pajak}

Hasil analisis menunjukkan bahwa kontrol perilaku menjadi penentu dari minat pelaku UMKM untuk menjadi wajib pajak, sehingga hipotesis ketiga pada penelitian ini diterima. Hasil ini menunjukkan bahwa kesulitan ataupun kemudahan pelaku UMKM terhadap kewajiban perpajakan mempengaruhi minat atau keinginan mereka untuk menjadi wajib pajak. Misalnya, apakah mereka mampu untuk melaporkan pajak, membuat perhitungan pajak dan membayar pajak menentukan minat mereka menjadi wajib pajak. Jika mereka merasa mampu untuk menghitung, melaporkan dan membayar pajak, pelaku UMKM cenderung ingin untuk memenuhi kewajiban perpajakan dengan menjadi wajib pajak. Sebaliknya, jika mereka merasa tidak mampu untuk melaporkan pajak, menghitung dan membayar pajak mereka cenderung untuk tidak ingin memenuhi kewajiban perpajakan.

Hasil penelitian ini mendukung penelitian yang dilakukan oleh (Bobek \& Hatfield, 2003) dan (Marthadiansyah et al., 2013) yang menemukan bahwa kontrol perilaku berpengaruh terhadap minat pelaku UMKM untuk menjadi wajib pajak. (Bobek \& Hatfield, 2003) menyatakan bahwa ketika individu merasa bahwa mereka dapat melaporkan pajak lebih rendah dari seharusnya mereka cenderung untuk menjadi wajib pajak, tetapi ketika mereka merasa tidak mampu untuk melaporkan pajak lebih rendah mereka cenderung untuk enggan menjadi wajib pajak. Jadi kontrol perilaku ini erat kaitannya dengan keyakinan dan kepercayaan diri individu akan kemampuannya mengontrol perilaku.

\section{Pengaruh Kontrol Perilaku terhadap Perilaku Pelaku UMKM menjadi Wajib Pajak}

Hasil penelitian menunjukkan bahwa kontrol perilaku berpengaruh terhadap perilaku UMKM untuk menjadi wajib pajak, sehingga hipotesis keempat pada penelitian ini diterima. Hampir sama dengan hipotesis ketiga, ketika seseorang individu, pelaku UMKM percaya akan kemampuannya untuk mengontrol perilaku perpajakannya (melaporkan pajak, menghitung, membayar, melaporkan lebih rendah) mereka memenuhi kewajiban perpajakannya. Jadi dapat dikatakan bahwa perilaku UMKM untuk memenuhi kewajiban perpajakannya (menjadi wajib pajak) muncul ketika mereka merasa dapat mengontrol pajak.

Hasil penelitian ini mendukung penelitian (Mustikasari, 2007) pada wajib pajak badan di Surabaya yang menunjukkan bahwa kontrol perilaku menjadi penentu perilaku UMKM dalam memenuhi kewajiban perpajaknnya. Ketika individu merasa bahwa adanya dapat dikendalikan atau dapat menguntungkan untuk dirinya maka perilakunya akan tergerak untuk memenuhi kewajiban perpajakannya. 
Determinan Kemauan Pelaku UMKM... Achmad Iqbal

Doi (https://doi.org/10.33506/sl.v9i1.692)

Pengaruh Pertanggungjawaban Pemerintah Atas Dana Pajak terhadap Minat Pelaku UMKM menjadi Wajib Pajak

Hasil penelitian menunjukkan bahwa pertanggungjawaban pemerintah atas dana pajak tidak berpengaruh terhadap minat pelaku UMKM untuk menjadi wajib pajak, sehingga hipotesis ke enam penelitian ini ditolak. Hal ini berarti UMKM menganggap bahwa sistem perpajakan dan penggunaan dana pemerintah yang berasal dari pajak tidak dipertanggungjawaban atau tidak dikeluarkan pada pos yang tepat. misalnya, adanya kasus-kasus yang menjerat politisi, pimpinan dirjen pajak, sehingga pelaku UMKM menganggap bahwa pertanggungjawaban pemerintah atas dana pajak ini masih rendah, yang pada akhirnya mempengaruhi keengganan mereka untuk memenuhi kewajiban perpajakan. Selian itu juga dikarenakan keengganan UMKM untuk mengetahui belanja publik, besarnya pendapatan negara yang berasal dari pajak, realisasi penerimaan pajak, serta dampak yang ditimbulkan dari adanya pajak juga turut menjadi penyebab ditolaknya hipotesis ke enam.

Penelitian ini menghasilkan hasil yang berbeda dengan penelitian sebelumnya mengenai pengaruh pertanggungjawaban pemerintah atas dana pajak terhadap minat WP. Hasil penelitian (Feld \& Frey, 2007) menemukan bahwa minat wp dipengaruhi salah satunya oleh pertanggungjawaban pemerintah terhadap penggunaan dana pajak. Perbedaan hasil ini dikarenakan adanya perbedaan dalam objek penelitian yang digunakan. pada yang dilakukan pada individu menemukan bahwa pertanggungjawaban mempengaruhi minat dikarenakan adanya manfaat yang diperoleh individu yang berasal dari pengeluaran pemerintah, misalnya adanya perbaikan jalan, sarana, bantuan sosial yang mereka temui disekitar tempat tinggal mereka. Sedangkan pada penelitian ini dengan objek pelaku UMKM, hampir UMKM tidak merasakan adanya pengeluaran pemerintah yang khusus ditujukan untuk UMKM misalnya peminjaman modal kerja bagi yang pembayaran pajaknya lancar.

\section{Pengaruh Minat terhadap Perilaku Pelaku UMKM menjadi Wajib Pajak}

Hasil analisis menunjukkan bahwa minat pelaku UMKM berpengaruh terhadap perilaku UMKM untuk menjadi wajib pajak, sehingga hipotesis ketujuh pada penelitian ini diterima. Minat merupakan keinginan mengenai seberapa jauh individu (UMKM) untuk mewujudkan keinginannya. Jadi dapat disimpulkan bahwa ketika pelaku UMKM mempunyai keinginan untuk menjadi WP, mereka akan segera mendaftarkan diri mereka sebagai WP. Sebaliknya ketika mereka tidak mempunyai keinginan untuk menjadi wajib pajak, tentu mereka tidak akan mendaftarkan diri mereka sebagai WP. Atau dalam kata lain, ketika pelaku UMKM berkeinginan untuk mematuhi peraturan perpajakan mereka cenderung untuk mendaftarkan diri sebagai WP, sebaliknya ketika keinginannya untuk patuh terhadap peraturan perpajakan tidak ada (rendah) mereka akan enggan untuk mendaftarkan diri sebagai wajib pajak.

Hasil penelitian ini sejalan dengan penelitian yang dilakukan oleh (Marandu et al., 2015) bahwa perilaku patuh seseorang terhadap ketentuan dan peraturan perpajakan ditentukan oleh keinginannya untuk patuh. Jadi dapat disimpulkan bahwa keinginan dan ketidak inginan 
Determinan Kemauan Pelaku UMKM... Achmad Iqbal

Doi (https://doi.org/10.33506/sl.v9i1.692) seseorang mampu menggerakan seseorang untuk patuh dan tidak patuh terhadap ketentuan dan peraturan perpajakan.

Hasil penelitian menunjukkan bahwa minatnya pelaku UMKM untuk menjadi wajib pajak di Banyuwangi ditentukan oleh sikap, kontrol perilakunya terhadap perpajakan. Adanya perasaan yang baik, pengendalian perilaku yang baik dan adanya moral yang baik tentu akan menjadikan minat atau keinginan bagi pelaku UMKM untuk menjadi Wajib Pajak. Yang pada akhirnya adanya minat atau keinginan yang baik dari pelaku UMKM, akan menelurkan perilaku yang baik/patuh terhadap kewajiban perpajakan.

\section{Simpulan}

Hasil penelitian menunjukkan bahwa minatnya pelaku UMKM untuk menjadi wajib pajak di Banyuwangi ditentukan oleh sikap dan kontrol perilakunya terhadap perpajakan. Adanya perasaan yang baik, pengendalian perilaku yang baik dan adanya moral yang baik tentu akan menjadikan minat atau keinginan bagi pelaku UMKM untuk menjadi Wajib Pajak. Pada akhirnya adanya minat atau keinginan yang baik dari pelaku UMKM, akan berimplikasi pada perilaku yang baik/patuh terhadap kewajiban perpajakan. Penelitian ini belum mempertimbangkan faktor tingkat pendidikan pelaku UMKM . Bagi penelitian selanjutnya untuk dipertimbangkan penambahan tingkat pendidikan dan adanya keikutsertaan pelaku usaha dalam sosialisasi perpajakan, sehingga dihasilkan hasil yang lebih kompleks.

\section{Ucapan Terima Kasih}

Terima kasih kepada Ristek Dikti atas hibah DRPM DIKTI tahun 2019 dan PPPM Universitas 17 Agustus 1945 Banyuwangi.

\section{Daftar Pustaka}

Ajzen, I. (1991). The theory of planned behavior. Orgnizational Behavior and Human Decision Processes, 50, 179-211. http://doi.org/10.1016/0749-5978(91)90020-T

Baridwan, Z. (2012). Analisis Keperilakuan Individu Terhadap Implementasi Sistem Informasi Akuntansi: Model Penerimaan dan Kesuksesan Sistem Informasi Berbasis Teknologi. Disertasi. Program Doktor Ilmu Akuntansi Universitas Brawijaya.

Basri, Y., \& Surya, R. (2014). Pengaruh keadilan, norma ekspektasi, sanksi dan religiusitas terhadap niat dan ketidakpatuhan pajak. Akuntabilitas, 7(3), 162-176.

Bobek, D., \& Hatfield, R. (2003). An Investigation of the Theory of Planned Behavior and the Role of Moral Obligation in Tax Compliance. Research in Accounting, 15, 13-38.

Feld, L., \& Frey, B. (2007). Tax Compliance as the Result of a Psychological Tax Contract: The Role of Incentives and Responsive Regulation. Law \& Policy, 29(1), 102-120.

Ferrari, L., \& Randisi, S. (2013). Fiscal psychology past and present : Contemporary experiments validate historical hypotheses. Journal of Ecomin Psychology, 35, 81-94. 
Determinan Kemauan Pelaku UMKM... Achmad Iqbal

Doi (https://doi.org/10.33506/sl.v9i1.692)

Fuadi, A., \& Mangoting, Y. (2013). Pengaruh Kualitas Pelayanan Petugas Pajak, Sanksi Perpajakan, dan Biaya Kepatuhan Pajak Terhadap Kepatuhan Wajib Pajak UMKM. Tax and Acoounting Review, 1(1), 18-27.

Hendri, N. (2016). Faktor-Faktor Yang Mempengaruhi Kepatuhan Wajib Pajak Pada UMKM di Kota Metro. Akuisisi, 1, 1-15.

Hidayat, W., \& Nugroho, A. (2010). Studi Empiris Theory of Planned Behavior dan Pengaruh Kewajiban Moral pada Perilaku Ketidakpatuhan Pajak Wajib Pajak Orang Pribadi. Jurnal Akuntansi Dan Keuangan, 12(2), 82-93.

Kogler, C., Batrancea, L., Nichita, A., \& Pantya, J. (2013). Trust and power as determinants of tax compliance: Testing the assumptions of the slippery slope framework in Austria, Hungary, Romania and Russia. Journal of Economic Psychology, 34, 169-180.

Lubis, M. (2011). Analisis Faktor-Faktor Yang Mempengaruhi Kesadaran Dalam Melaporkan Kewajiban Perpajakan Pada Sektor UKM di Kota Medan. Jurnal Riset Akuntansi Dan Bisnis, 11(2), 171-190.

Lunney, A., Cunningham, N. R., \& Eastin, M. S. (2016). Wearable fitness technology: A structural investigation into acceptance and perceived fitness outcomes. Computers in Human Behavior, 65, 114-120. http://doi.org/10.1016/j.chb.2016.08.007

Marandu, E., Mbekomize, C., \& Ifezue, A. (2015). Determinants of Tax Compliance : A Review of Factors and Conceptualizations. International Journal of Economics and Finance, 7(9), 207-218.

Marthadiansyah, Meutia, I., \& Mukhtgarudin. (2013). Empirical Studies of Tax Payer Compliance on Tax Filling: Applying Theory of Planned Behavior. In In 3rd Annual International Conference on Accounting and Finance.

Mustikasari, E. (2007). Kajian Empiris tentang Kepatuhan Wajib Pajak Badan di Perusahaan Industri Pengolahan di Surabaya. In SImposium Nasional Akuntansi X.

Wicaksono, R. (2016). Faktor-Faktor Yang Mempengaruhi Kepatuhan Wajib Pajak Usaha Mikro, Kecul, dan Menengah (UMKM) dalam Membayar Pajak Sesuai PP No. 46 Tahun 2013 Pada UMKM di Kabupaten Bantul. JUrnal Fokus BIsnis, 15(2), 1-21.

Widyati, K. (2018). Faktor-Faktor Yang Mempengaruhi Kemauan Usaha Mikro, Kecil, dan Menengah Menjadi Wajib Pajak. Jurnal Ilmiah Mahasiswa FEB, 6(2). 